\title{
ПРОБЛЕМА РЕАЛИЗАЦИИ УГОЛОВНО-ПРАВОВЫХ МЕР БОРЬБЫ С ОРГАНИЗОВАННОЙ ПРЕСТУПНОСТЬЮ
}

\author{
Эминов В.E.
}

Аннотация: Автор подробно рассматривает такие аспекты реализации уголовно-правовых мер борьбы с организованной преступностью как комплекс мер политического, сочиально-экономического, информачионно-пропагандистского, организационного, правового и иного характера, осуществляемых государственными органами, органами местного самоуправления, общественными объединениями и иными организациями, и направленных на нейтрализацию криминальных процессов в обществе, сдержсивание преступности и сокращение темпов ее роста. Автор выделяет и рассматривает два уровня предупреждения организованной преступности: общесочиальный и специально-криминологический. Методами проведенного исследования являются сравнительно-правовой, диалектический, анализ, синтез, исторический, оценок, структурно-функииональный, системный, модерирования. Основными результатами исследования явились выводы, к которым пришел автор, а именно:в системе предупреждения преступности можно выделить два уровня: общесоциальный (ликвидация кризисных явлений в экономике, политике, общественной идеологии и психологии, социиальной сфере, а также в правоохранительной деятельности) и специально-криминологический (включает в себя деятельность правоохранительных органов по выявлению и анализу причин и условий, способствующих совершению преступлений, привлечению к работе по предупреждению преступлений общественных объединений правоохранительной направленности и граждан.

Ключевые слова: Проблема, реализация, мер, борьба, организованная преступность, безопасность, преступление, противодействие, противоправное поведение, правоохранительная деятельность.

Одной из основных проблем, широко обсуждаемой в последнее время в криминологической литературе, является определение терминологии при обозначении социальной деятельности, направленной на снижение уровня преступности, ослабление или нейтрализацию ее причин и условий. Предлагается использовать универсальный термин «противодействие преступности», включающий в себя комплекс мер политического, социально-экономического, информационно-пропагандистского, организационного, правового и иного характера, осуществляемых государственными органами, органами местного самоуправления, общественными объединениями и иными организациями, и направленных на нейтрализацию криминальных процессов в обществе, сдер- 
живание преступности и сокращение темпов ее роста. В системе предупреждения преступности можно выделить два уровня: общесоциальный и специально-криминологический. Общесоциальный уровень предполагает ликвидацию кризисных явлений в экономике, политике, общественной идеологии и психологии, социальной сфере, а также в правоохранительной деятельности. Как отмечается в Стратегии национальной безопасности Российской Федерации до 2020 года, Российская Федерация (наряду с достижением основных приоритетов национальной безопасности) сосредоточивает свои усилия и ресурсы на следующих приоритетах устойчивого развития: повышение качества жизни российских граждан путем гарантирования личной безопасности, а также высоких стандартов жизнеобеспечения; экономический рост, который достигается, прежде всего, путем развития национальной инновационной системы и инвестиций в человеческий капитал. Основной задачей общесоциального предупреждения выступает создание предпосылок для невыгодности противоправной деятельности, в первую очередь, с точки зрения экономической нецелесообразности. Специально-криминологический уровень включает в себя деятельность правоохранительных органов по: - выявлению и анализу причин и условий, способствующих совершению преступлений, принятию мер по их устранению или нейтрализации; - выявлению и постановке на профилактические учеты лиц, склонных к совершению преступлений; - установлению лиц, осуществляющих приготовление к преступлению и (или) покушение на преступление, и принятию мер по пресечению их противоправной деятельности; - привлечению к работе по предупреждению преступлений общественных объединений правоохранительной направленности и граждан. Специально-криминологическое предупреждение подразделяется на меры неперсонифицированного характера, направленные на устранение криминогенных факторов, и меры, адресованные конкретным лицам с отклоняющимся поведением. В связи с этим следует различать две разновидности специально- криминологического предупреждения преступлений: общее и индивидуальное. Предупреждение организованной преступности предполагает создание такого механизма, при котором осуществляется целенаправленное воздействие на причины и условия (детерминанты), ее порождающие и способствующие ее развитию. В этом отношении правильно говорить о минимизации влияния организованной преступности на все сферы социальной жизни до уровня, не угрожающего безопасному существованию личности, реализации приоритетных реформ, государственных программ, направленных на обеспечение устойчивого роста уровня жизни граждан и поддержание национальной безопасности. Еще одна важнейшая цель - это установление эффективного социального контроля над организованной преступностью, препятствующего стихийному (непредвиденному) росту ее объемов и общественной опасности, появлению новых видов организованной преступности (В. Е. Эминов, А. Л. Репецкая). Важнейшим фактором, предопределяющим успех в противодействии организованной преступности, выступает политическая воля руководства страны. Только в этом случае можно достичь реальных успехов в снижении уровня организованной преступности и ее фоновых явлений (коррупции и другое). Главным индикатором жизнеспособности системы противодействия преступности выступает оптимизация правоохранительной деятельности, повышение ее эффективности. Необходимо комплексно воздействовать на процессы, связанные с распространением организованной преступности и вовлечению в нее населения, стремиться к тому, чтобы эти вопросы стали предметом специального государственного регулирования. Речь идет о разработке государственной концепции противодействия организованной преступности, на что обращалось внимание в последних решениях Совета Безопасности Российской Федерации. Не менее значима работа по решению тактических задач предупреждения организованной преступности, важнейшая из которых - оперативно-розыскная профилактика. Помимо этого, к наиболее важным, 
требующим первоочередного внимания, аспектам следует отнести: - совершенствование структуры правоохранительных органов; - создание в Главном информационно-аналитическом центре МВД России для регистрации и учета данных об организованной преступности межведомственного банка данных на региональные, межрегиональные и транснациональные преступные группы и сообщества; - обеспечение надлежащей защиты потерпевшим, свидетелям и иным участникам уголовного судопроизводства; - международное сотрудничество на основе реализации Конвенции Организации Объединенных Наций против транснациональной организованной преступности и дополняющих ее протоколов; - противодействие легализации (отмыванию) доходов, полученных преступным путем; - информационнопропагандистское обеспечение предупреждения организованной преступности. Полномочия МВД России по выявлению, предупреждению, пресечению и расследованию тяжких и особо тяжких преступлений, совершенных организованными группами и преступными сообществами, следует рассматривать как постоянную обособленную функцию государства, для обеспечения которой необходима самостоятельная федеральная служба по борьбе с наиболее опасными видами организованной преступности. Задачами ее подразделений должны являться: - проведение мониторинга оперативной обстановки в сфере борьбы с организованной преступностью с привлечением специалистов научных и научно-исследовательских учреждений; - принятие мер по разобщению организованных групп и преступных сообществ на ранних стадиях формирования путем поиска и своевременной реализации информации упреждающего характера; - проведение оперативнорозыскных мероприятий по предупреждению преступлений, отнесенных к их компетенции, в том числе по предупреждению противоправной деятельности участников организованных групп и преступных сообществ; - осуществление мероприятий по недопущению проникновения представителей организованных групп и преступных сообществ в органы власти; - разработка и орга- низация проведения специальных операций и оперативно-профилактических мероприятий в сфере борьбы с организованной преступностью; - выявление при проведении оперативно-розыскных мероприятий причин и условий, способствующих совершению преступлений, принятие в пределах компетенции мер по их устранению, проведение других оперативно-профилактических мероприятий. Отмечается, что основной задачей современного законотворчества выступает устранение выявленных пробелов и коллизий, приведение нормативно-правовой базы в полное соответствие с социально-экономическими реалиями, генеральным политическим курсом российского государства, а также его международными обязательствами. Несовершенство законодательства снижает его авторитет и эффективность, формирует у правоприменителя избирательное отношение к уголовно-правовым средствам противодействия преступности. В процессе реконструкции ч. 4 ст. 35 и ст. 210 УК РФ Федеральным законом от 3 ноября 2009 г. № 245-Ф3 российским законодателем был учтен ряд положений Конвенции ООН против транснациональной организованной преступности. [1] Смысл законодательных изменений заключается, вопервых, в более подробном описании признаков объективной стороны состава организации преступного сообщества (преступной организации) или участия в нем (ней), и, во-вторых, в ужесточении ответственности за данное общественно опасное деяние, в том числе и в отношении лиц, занимающих «высшее положение в преступной иерархии» (ч. 4 ст. 210 УК РФ). Одним из векторов развития уголовного законодательства в современный период является минимизация оценочных признаков, препятствующих единообразному применению уголовно-правовых норм. Это требование должно соблюдаться и при конструировании правовых предписаний, касающихся ответственности за организованную преступную деятельность, эффективность реализации которой напрямую зависит от качества законодательной техники. Так, наличие ряда не поддающихся формализации признаков в ст. 210 УК РФ (напри- 
мер, лицо, использующее свое влияние на участников организованных групп; лицо, занимающее высшее положение в преступной иерархии) и обусловленные этим проблемы при их разграничении оказывают негативное влияние на восприятие соответствующих норм судебно-следственными органами. В связи с этим привлечение к ответственности лиц за организацию преступного сообщества (преступной организации) или участие в нем (ней) по-прежнему остается проблематичным. Наиболее перспективными способами такой формализации выступают бланкетный способ описания признаков и судебное толкование. В целях устранения конкуренции и противоречия между признаками отдельных форм соучастия и составов преступлений, устанавливающих ответственность за организованную преступную деятельность, предлагается: 1) признать незаконное вооруженное формирование (ст. 208 УК РФ) и некоммерческую организацию, посягающую на личность и права граждан (ст. 239 УК РФ), разновидностями организованной группы; 2) в соответствии с правилом законодательной техники об экономии нормативного материала в ч. 4 ст. 35 УК РФ сформулировать понятие преступного сообщества, а в ст. 210 УК РФ ограничиться лишь указанием на признаки объективной стороны - создание преступного сообщества, руководство им или входящими в него структурными подразделениями и участие в нем; 3) вследствие неопределенности и оценочного характера признаков, указанных в ч. 4 ст. 210 УК РФ, и с учетом отсутствия практики применения данной нормы, исключить квалифицирующее обстоятельство о совершении деяний «лицом, занимающим высшее положение в преступной иерархии». Достаточно сложным для правовой оценки является вопрос о том, в совершении каких конкретных действий может выражаться участие в запрещенных уголовным законом объединениях, и какова должна быть степень такого участия. Делается вывод о том, что: 1. Участие в объединениях, ставящих перед собой цель совершения преступлений, выражается в совершении конкретных, предусмотренных УК РФ, общест- венно опасных деяний в интересах этих объединений (непосредственном совершении, совершении в соучастии, приготовлении и покушении к таким преступлениям). 2. Участие должно быть активным, деятельным, и не может выражаться в простом бездейственном членстве в преступном объединении. 3. Лицо может считаться членом преступного объединения только тогда, когда оно существенно способствует его функционированию. 4. Участие в преступном объединении должно признаваться оконченным преступлением, когда лицо не просто даст согласие на вступление в него, а обязательно подкрепит это конкретной практической деятельностью, выполнит любые действия, вытекающие из факта принадлежности к деятельности соответствующей криминальной структуры. Анализируются поощрительные нормы, позволяющие освободить от уголовной ответственности участников преступных объединений при условии их позитивного посткриминального поведения. Установив возможность освобождения от ответственности участников преступных сообществ (преступных организаций), входящих в него (нее) структурных подразделений либо собраний организаторов, руководителей (лидеров) или иных представителей организованных групп, законодатель не предусмотрел аналогичного положения в отношении участников организованных преступных групп. По мнению диссертанта, предпочтительнее было бы закрепить общее основание освобождения от уголовной ответственности участников групповых преступлений. Одним из вариантов решения обозначенной проблемы было бы введение в главу 11 УК РФ «Освобождение от уголовной ответственности» ст. 76.2 следующего содержания: «Статья 76.2. Освобождение от уголовной ответственности участников организованных групп и преступных сообществ Лицо, добровольно прекратившее участие в организованной группе или преступном сообществе и активно способствовавшее пресечению деятельности такой группы (сообщества), раскрытию преступлений, совершенных и (или) планируемых такой группой (сообществом), может быть освобождено 
от уголовной ответственности за все совершенные им преступления, за исключением особо тяжких преступлений, посягающих на жизнь». Одновременно с этим следует исключить поощрительные примечания к ст. 208, ст. 210 и ст. 282.1 УК РФ. В качестве одной из мер по противодействию организованным формам преступности следует рассматривать институт досудебного соглашения о сотрудничестве. Законодательное оформление данной процедуры повышает результативность в раскрытии и расследовании наиболее опасных преступлений, в том числе совершенных организованными преступными группами и сообществами. Вместе с тем, в целях преодоления существующих противоречий между положениями УК РФ о назначении наказания при наличии досудебного соглашения о сотрудничестве и практикой их применения предлагается исключить из ч. 2 ст. 62 слова «и отсутствии отягчающих обстоятельств». «Проблемы обеспечения правовой защиты лиц, выполняющих специальное задание по пресечению или раскрытию деятельности организованной группы или преступного сообщества» рассматривается проблема рассогласования предписаний уголовно-правового характера, содержащихся в Федеральном законе «Об оперативно-розыскной деятельности», и положений УК РФ. Высказывается предложение о включении в УК РФ ст. 42 «Выполнение специального задания по пресечению либо раскрытию деятельности организованной группы или преступного сообщества» следующего содержания: «Статья 42 . Выполнение специального задания по пресечению либо раскрытию деятельности организованной группы или преступного сообщества. 1. Не является преступлением причинение вреда охраняемым уголовным законом интересам лицом, выполнявшим в соответствии с действующим законодательством специальное задание по пресечению либо раскрытию деятельности организованной группы или преступного сообщества, если отказ от причинения такого вреда был сопряжен с угрозой для жизни этого лица либо с угрозой его разоблачения со стороны участников организованной группы или преступ- ного сообщества и невыполнения этим лицом своего задания. 2. Положения настоящей статьи не распространяются на лиц, совершивших общественно опасное деяние, связанное с посягательством на жизнь человека».

невозможно понять сущность проблемы без выяснения основ политической безопасности и ее места в структуре национальной безопасности государства. Кроме того, автора волновал вопрос о том, чьи интересы призвана защищать политическая безопасность и почему угроза криминализации общества является актуальной для большинства развитых и развивающихся стран мира? В ходе исследования автор пришел к выводу, что политическая безопасность является одним из основополагающих компонентов структуры национальной безопасности. Под политической безопасностью автор понимает совокупность мер для беспрепятственной реализации прав и свобод граждан, а также защиту политических интересов личности, общества и государства от воздействия организованной преступности, как одного из потенциальных источников внутренних и внешних угроз. Организованная преступность, по мнению автора - это группа устойчивых асоциальных объединений, осуществляющих противозаконную деятельность, направленную на причинение максимального экономического и/или физического ущерба, а также создающих препятствия для свободной реализации политических прав и свобод личности, общества, и государства. Основными целями которой, является создание и развитие организованных преступных групп, направленных на: извлечение сверхдоходов и приумножение капитала, добываемого преступным путем; У установление политического влияния в государстве посредством лоббирования и/или участия в предвыборной борьбе. Наиболее типичной причиной зарождения организованных преступных групп могут быть экономические и политические катаклизмы в государстве. Однако преступность может проникать из других стран, быстро адаптируясь на новом месте, а также образоваться в любом государстве из 
неустроенной среды иммигрантов. В процессе исследования был проведен анализ степени воздействия организованной преступности на национальные и политические интересы РФ, в результате которого, было установлено, что политическая безопасность представляет собой один из основных объектов для деструктивной деятельности организованной преступности. Этот вывод находит отражение в ряде направлений деятельности организованной преступности. Среди них: - выдвижение своего кандидата на выборах в государственные органы власти. финансирование одного из потенциальных кандидатов, собственное баллотирование в муниципальные, региональные или федеральные структуры власти; - материальное, моральное и/ или физическое воздействие на представителей власти. материальное и/или физическое воздействие на электорат; - лоббирование преступных интересов. В процессе исследования была также определена методологическая основа исследования характера и механизмов воздействия организованной преступности на деятельность субъектов российской политики. На основе многочисленных научных материалов автору удалось разработать методологию исследования характера и механизмов воздействия организованной преступности на деятельность субъектов российской политики. В качестве важнейших методов воздействия организованной преступности на целостную структуру государственной власти, следует рассмотреть: механизм коррумпирования чиновников и представителей органов правопорядка. применение силовых методов воздействия в качестве средства ликвидации отдельных представителей исполнительной и судебной власти, препятствующих преступной деятельности ОП. применение уголовного терроризма, а также уголовной экстремистской деятельности в качестве способов дестабилизации государственной власти. В заключительной части работы автором были предложены приоритетные направления совершенствования государственной политики в области противодействия организованной преступности в России. Указанные направления заключаются в максимально рациональных и согласованных действиях различных государственных органов (в том числе правоохранительных) и общественных организаций по противодействию организованной преступности. Противодействие организованной преступности в предложенной программе осуществляется посредством: а) обеспечения надлежащего правового регулирования деятельности по борьбе с организованной преступностью; б) обеспечения системного анализа процессов, происходящих в криминальной среде; в) планирования, организации и координации деятельности государственных служб и иных организаций по противодействию преступности; г) совершенствования организации и тактики деятельности государственных органов, осуществляющих противодействие организованной преступности; д) совершенствования системы информационного, финансового, материальнотехнического и иного обеспечения деятельности по борьбе с организованной преступностью; е) обеспечения контроля и надзора за деятельностью по борьбе с организованной преступностью; совершенствования социальной, ситуационной и пенитенциарно-правовой превенции; ж) осуществления виктимологической профилактики.

\section{Библиография:}

1. Федеральный закон от 3 ноября 2009 г. № 245-Ф3

\section{References (transliterated):}

1. Federal'nyi zakon ot 3 noyabrya 2009 g. № 245 -FZ 